\title{
TWEE CHINESE BEDDENSPREIEN IN HET RIJKSMUSEUM
}

Het Rijksmuseum bezit een kleine collectie Chinese zijden weefsels die in de $17^{\mathrm{e}}$ en $18^{\mathrm{e}}$ eeuw als handelswaar van de Verenigde Oostindische Compagnie of als souvenirs en particuliere handelswaar van haar dienaren naar Nederland zijn verscheept. Twee Chinese geborduurde beddenspreien zijn de spil van dit artikel. Een daarvan is in de loop der tijd drastisch van gedaante verwisseld, van sprei naar kazuifel. De verwerving van deze kazuifel vormde de aanleiding de Chinese export-zijdeweefsels in het museum als geheel onder de loep te nemen, om de aanwinst in perspectief in dit artikel te kunnen presenteren. Zoals vaker het geval is, blijken juist deze twee spreien een hoofdrol in het verhaal te kunnen spelen, omdat over hun herkomstgeschiedenis het meest bekend is. Voorwerpen winnen aan betekenis naarmate er meer over de opdrachtgevers, eigenaren, gebruikers en latere geschiedenis van het object bekend is, zo blijkt maar weer.

\section{De sprei van Lucia van Lilaar van Stoutenburg}

Het Rijksmuseum verwierf in 2008 een set liturgische kledij bestaande uit een kazuifel, stola, manipel (smalle doek voor over de linker arm van de officiant), velum (doek voor over de miskelk) en bursa (bewaarplaats voor de kelkdoek tijdens de mis) (afb. 1-5). Deze paramenten zijn vervaardigd uit $18^{\mathrm{e}}$ eeuwse Chinese gele zijde, die rijkelijk is voorzien van veelkleurig borduurwerk: bloemen, rankwerk, Europese ornamentele banden en zelfs haasjes. De kazuifel is versierd met een kruis, met in het centrum een grote bloem, die meteen in het oog springt. De zijde heeft een glanzend oppervlak dankzij de satijnbinding en dit zorgt samen met de heldere kleuren van het borduurwerk voor een rijke uitstraling. Op grond van het goudgalon dat gebruikt is om het kruis weer te geven, mag aangenomen worden dat de paramenten in de eerste helft van de $19^{e}$ eeuw uit de geborduurde zijde zijn vervaardigd.

Over de herkomst van de paramenten bestaat spaarzame, maar intrigerende informatie. In 1966 gaf de verzamelaar van vooral kerkelijke kunstnijverheidvoorwerpen, H.A.A. van Harten (1922-2001) uit Baarn, ze in bruikleen aan het Rijksmuseum. ${ }^{1}$ Bij die gelegenheid werd op het bruikleenformulier vermeld dat kazuifel en toebehoren vervaardigd waren 'van een als een votiefgeschenk gegeven trouwjapon van de barones van Stoutenburg.' De ontvanger was, zo werd eveneens op het formulier vermeld, de Sint Franciscus Xaveriuskerk aan 't Zand in Amersfoort, in de $18^{\mathrm{e}}$ en $19^{\mathrm{e}}$ eeuw een van de bloeiendste en belangrijkste parochies in Nederland. ${ }^{2}$

Deze informatie blijkt helaas niet meer tot volle tevredenheid te verifiëren. ${ }^{3}$ Bekend is dat Van Harten een gerenommeerd verzamelaar was met goede contacten in het Rijksmuseum, en het Aartsbisschoppelijk Museum in Utrecht. Beide instellingen verwierven voorwerpen van hem, soms in de vorm yan $\mathrm{Br}_{\text {e }}$ access 


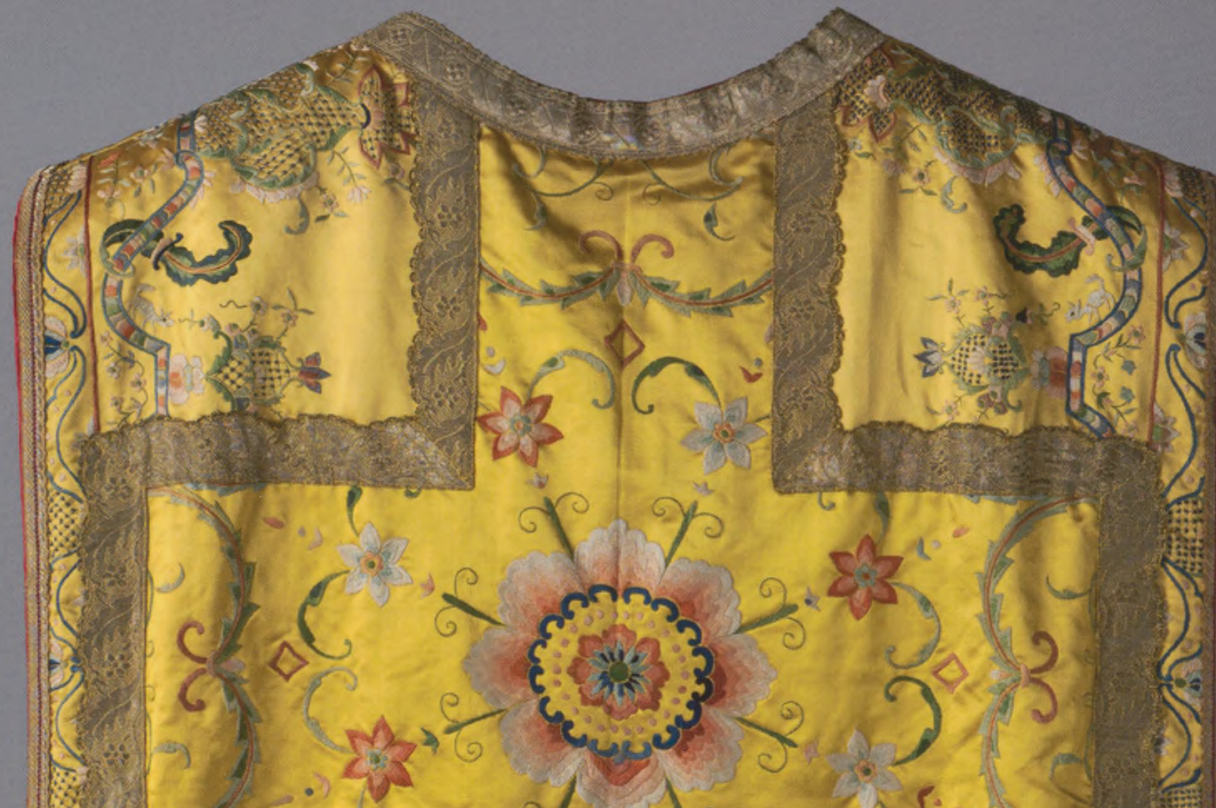

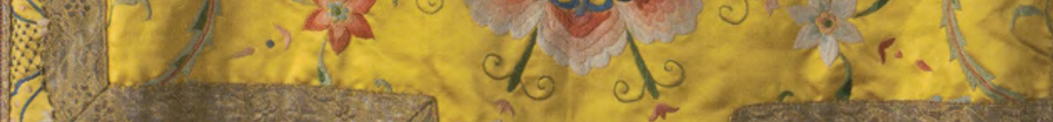

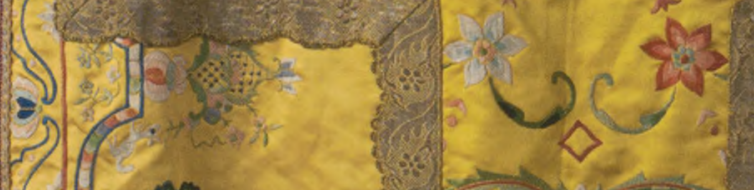

13 a

(3) $12 x^{2} \mathrm{c}$

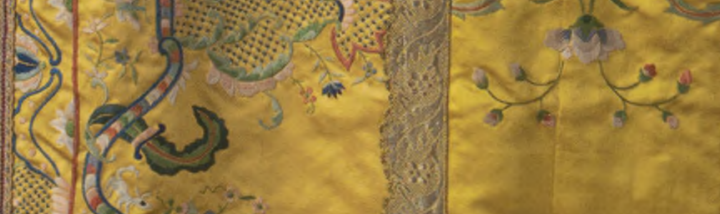

S.) $x^{2} \times 2$

30 ?

(1) 15 .

(x) 1.0

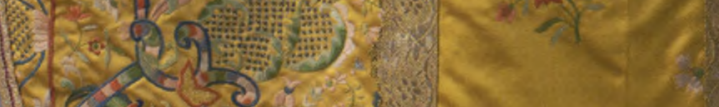

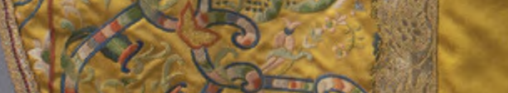
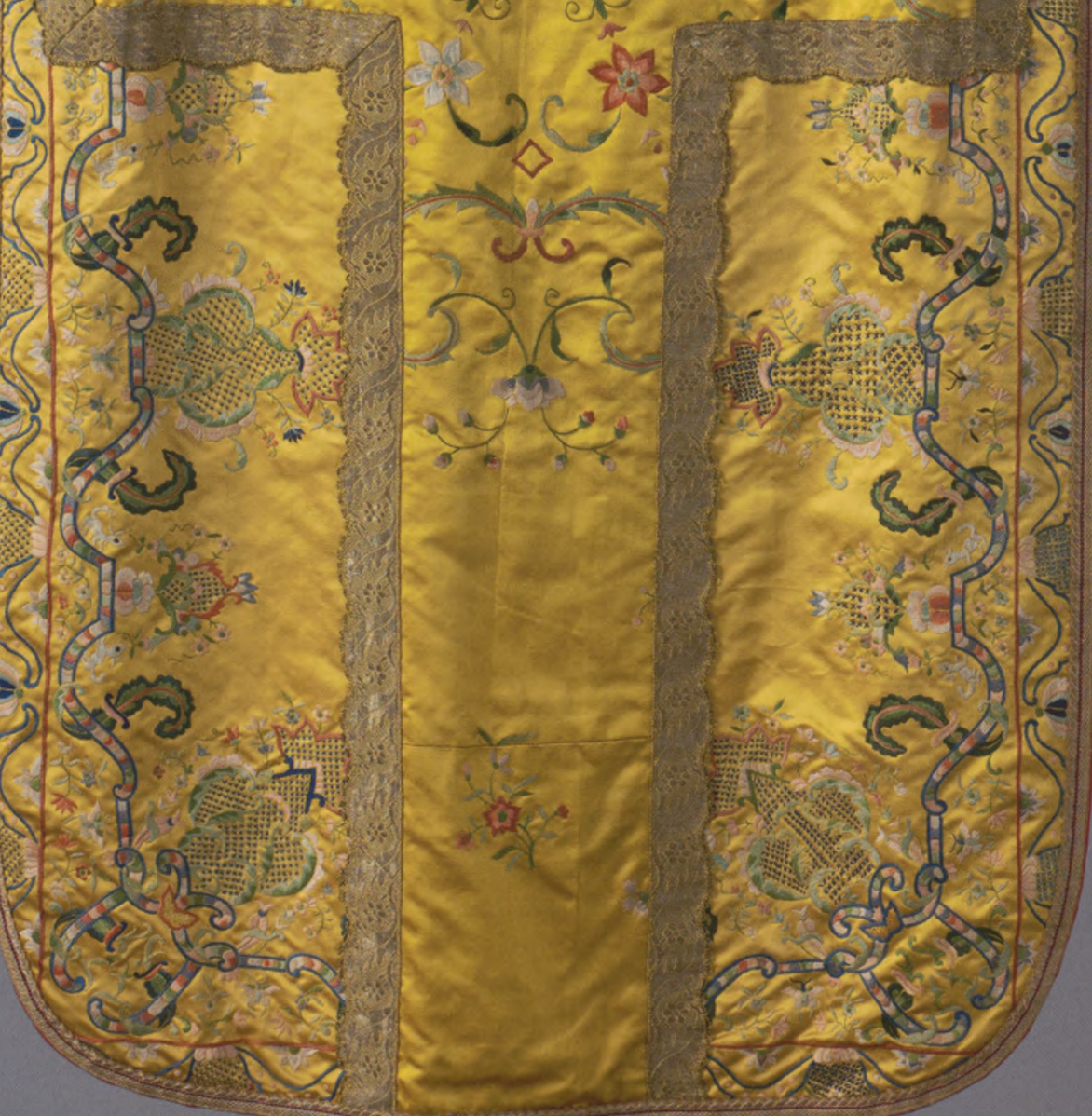
< Afbeelding 1 Kazuifel, Chinese geborduurde zijde, midden $18^{e}$ eeuw, hoogte $108 \mathrm{~cm}$, BK-2008-176-A
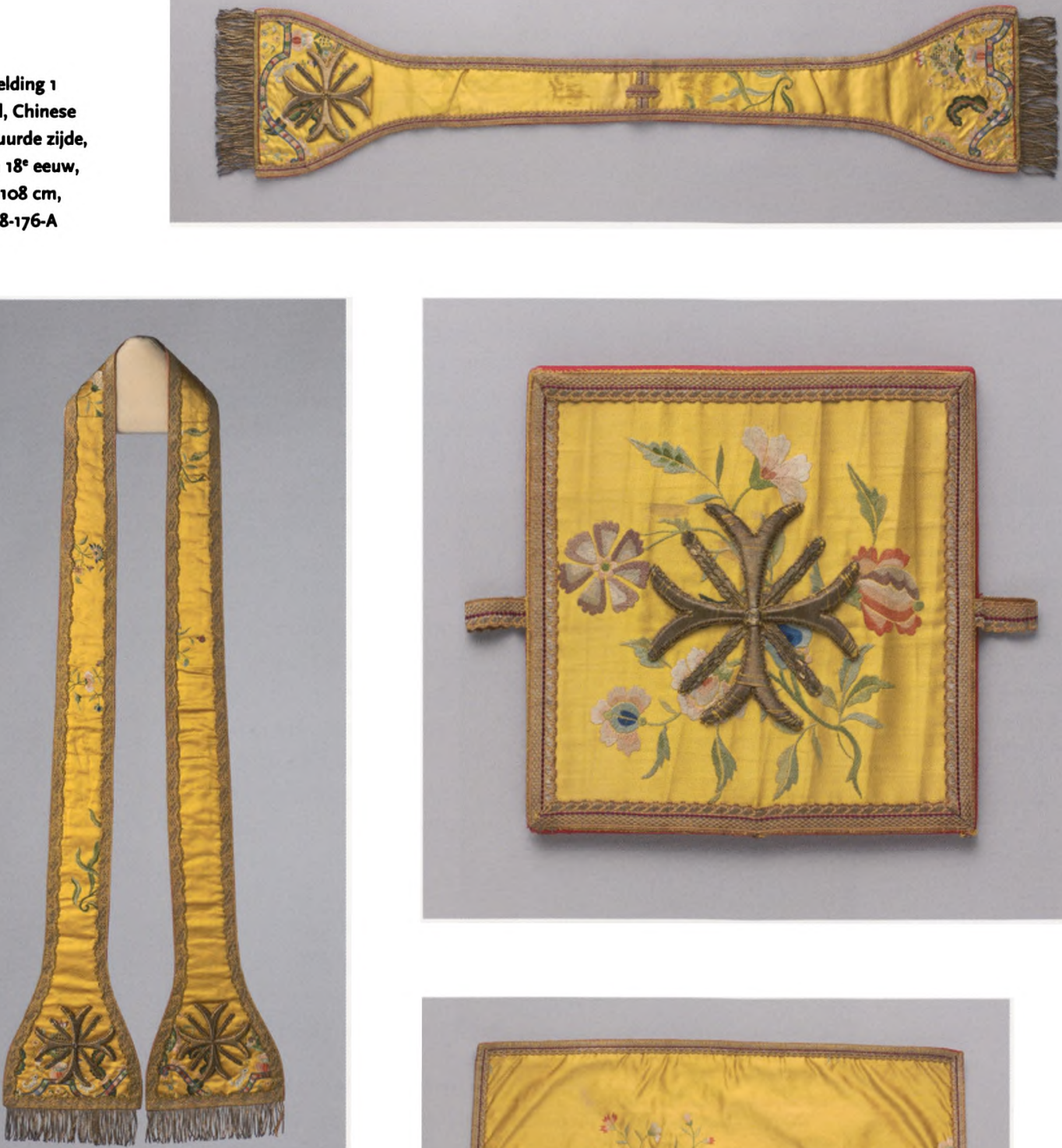

Afbeelding 2 Stola, lengte $228 \mathrm{~cm}$, BK-2008-176-B
Afbeelding 3

Manipel, lengte $98 \mathrm{~cm}$, BK-2008-176-C

\section{Afbeelding 4}

Velum, lengte $57 \mathrm{~cm}$,

BK-2008-176-E

Afbeelding 5

Bursa, lengte $22 \mathrm{~cm}$,

BK-2008-176-D
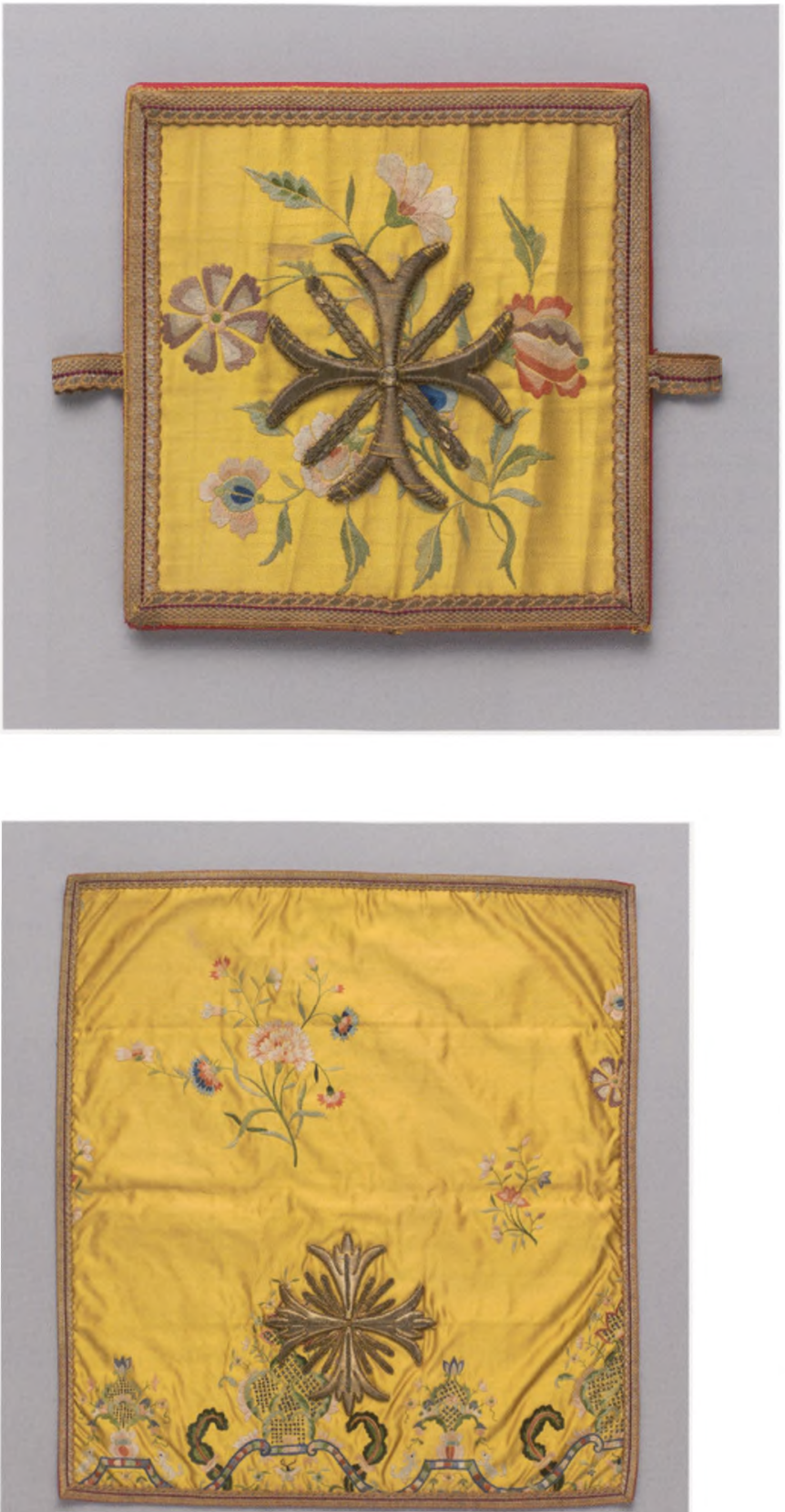
bruiklenen. Een van de bronnen voor zijn rijke collectie was de Franciscus Xaveriuskerk in Amersfoort, hoewel over de verwerving van deze paramenten in de archieven van de kerk niets kon worden gevonden. ${ }^{4}$ Aangezien de herkomstinformatie zo specifiek is, omdat Van Harten als een serieuze verzamelaar geldt en omdat er op z'n minst een opmerkelijke band heeft bestaan tussen 'de barones van Stoutenburg' en de Xaveriuskerk, is het toch de moeite waard hier iets verder op in te gaan.

Met de barones van Stoutenburg kan niemand anders bedoeld zijn dan Lucia Theresia van Lilaar (sterft in 1819 op 67-jarige leeftijd), vrouwe van Stoutenburg en echtgenote van baron Petrus Leonardus van Heilmann (-1821) (afb. 6). ${ }^{5}$ Het huis Stoutenburg, nabij Amersfoort, was tot 1792 bewoond door Lucia's vader, Jan Francois van Lilaar (1727-1792). De Van Lilaars waren welgestelde bierbrouwers en tabaksplanters. Jan Francois woonde aanvankelijk in Amsterdam, vanaf 1783 in Amersfoort, en had Stoutenburg als
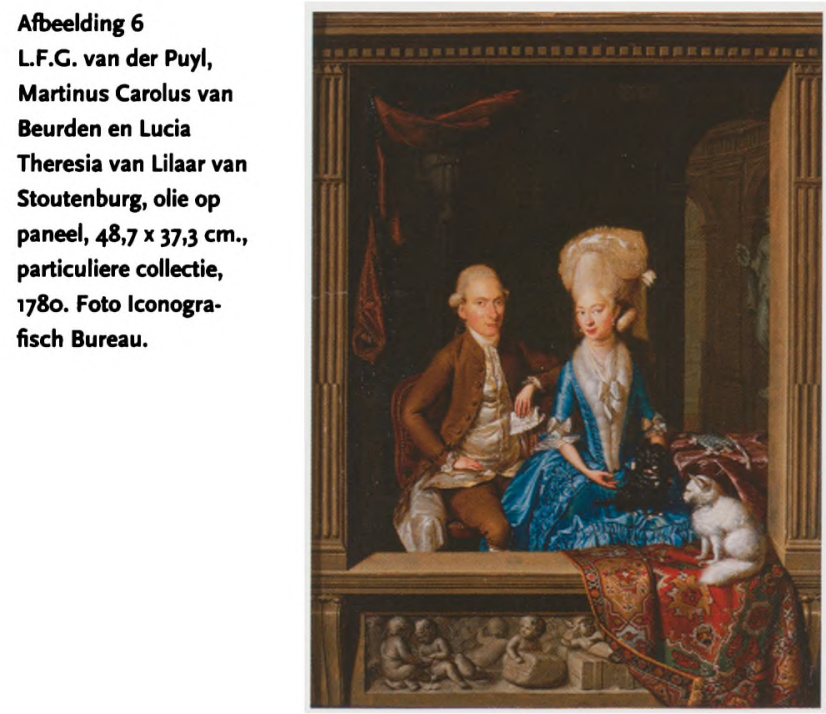

buitenplaats. Ook Lucia woonde aanvankelijk in Amsterdam. Zij was getrouwd met Carolus van Beurden, die in 1787 overleed. Al in 1789 hertrouwde zij met baron Van Heilmann uit Luik. Aanvankelijk woonden zij in de winter in Utrecht, vanaf 1812 in het huis Rommelenburg in de muurhuizen in Amersfoort, een van de grootste huizen van de stad. De zomers werden vanaf 1793 doorgebracht op Stoutenburg. In 1819 stierf Lucia kinderloos. De waarde van haar nalatenschap bedroeg 375.000 gulden. $^{6}$

De Van Lilaars waren overtuigde katholieken en er bestaan verschillende aanwijzingen voor hun geloofsijver. De eerste echtgenoot van Lucia vroeg haar 41.000 gulden na te laten aan de Leidse katholieke armen. Dit legaat is inderdaad in Lucia's testament terug te vinden. Op Stoutenburg bevonden zich in verschillende vertrekken knielbankjes, 'ornamenten tot een altaar', een bidstoel, crucifix en vijf miskleden. Op Rommelenburg was zelfs een 'zwart carsuiffel' aanwezig. Van een grote interesse voor Aziatische voorwerpen blijkt uit de boedelbeschrijving niet veel. Wél opvallend is een ruime aanwezigheid van sitsen dekens, spreien en gordijnen en zelfs van een 'chitse kamer' op Stoutenburg, en in het stadshuis wordt 'een geel zijde sprey met lappen van het zelver' genoemd. 
De speciale band met de Xaveriuskerk van de Van Lilaars komt naar voren in de kerkrekeningen en het kasboek van de Sint Franciscus Xaveriusparochie. ${ }^{7}$ Zeer regelmatig traden de Van Lilaars op als financiers van de kerk. Kerk en inboedel stonden zelfs tot 1795 op naam van A.F. van Lilaar, een oom van Lucia, aangezien rooms-katholieke instellingen geen bezit mochten hebben. In dat jaar tekende Van Lilaar een acte van afstand, en toonde zijn voortgaande betrokkenheid door lid te worden van het kerkbestuur. ${ }^{8}$

De grote bloem midden op de rug van de kazuifel blijkt een motief te zijn dat regelmatig voorkomt op Chinese geborduurde beddenspreien die in de $18^{e}$ eeuw in Europa werden ingevoerd. Een exemplaar met een zeer vergelijkbare centrale bloem bevindt zich in de collectie van het Victoria and Albert Museum in Londen. ${ }^{9}$ Ervan uitgaande dat Van Harten over de herkomst in principe juist was geïnformeerd, ligt het toch meer voor de hand dat de paramenten van een beddensprei zijn gemaakt dan van een trouwjapon en de gele zijden sprei met enkele bijbehorende losse lappen in het Amersfoortse sterfhuis van Lucia van Lilaar kunnen goed de basis van de kazuifel zijn geweest. ${ }^{10}$ Wellicht was de sprei al van haar ouders geweest. Zij dateerde immers uit het midden van de eeuw, ongeveer de tijd dat haar ouders trouwden. Het was voor Lucia in ieder geval een oud stuk textiel.

De 'legende van de trouwjapon' was niet volledig uit de lucht gegrepen. In de $18^{\mathrm{e}}$ eeuw schonken voorname leken hun kleding aan de kerk voor hergebruik in de vorm van paramenten. Voorbeelden van schenkingen door hooggeplaatste lieden uit verschillende Europese landen zijn bekend en kleding werd zelfs aan de kerk verkocht. Er is één interessant Nederlands voorbeeld bekend - notabene uit Amersfoort: de vermeende trouwjapon van Wilhelmina van Pruisen, die zij geschonken zou hebben aan de Joodse gemeente in Amersfoort om er een parochet van te maken, een voorhang of gordijn voor de Heilige Ark in de synagoge, waarin zich de Torarollen bevinden. ${ }^{11}$ Wilhelmina schonk overigens niet haar trouwjapon, maar een japon uit haar uit Pruisen meegenomen trousseau.

\section{Chinese zijde in kerkelijke gewaden}

Het gebruik van Chinese stoffen in kerkelijke gewaden is niet bijzonder zeldzaam, maar in de meeste gevallen werden zij geheel in China vervaardigd en niet - zoals in het geval van de Van Lilaar-kazuifel - in Nederland of elders uit Chinese stoffen samengesteld.

Uiteraard is deze kerkelijke kledij vooral in katholieke landen te vinden, in Europa, maar ook in Aziatische gebieden met een sterke katholieke aanwezigheid zoals op de Filippijnen. Er zijn echter ook exemplaren bekend die voor Nederlandse opdrachtgevers werden gemaakt, zoals een prachtige kazuifel in Museum Catharijneconvent, in het midden van de $18^{\mathrm{e}}$ eeuw in China vervaardigd voor het Amsterdamse Hofje der Zeven Keurvorsten, waarin niet alleen in het centrum van het kruis een madonna met kind is geborduurd, maar ook aan de onderzijde van de kazuifel een familiewapen van een van de weldoeners van het hofje (afb. 7). ${ }^{12}$

Chinese stoffen werden echter al veel vroeger in kerkelijke gewaden en andere kleding gebruikt. In de $13^{\mathrm{e}}$ en $14^{\mathrm{e}}$ eeuw, tijdens de Chinese Yuandynastie (1279-1368), bereikten Chinese stoffen Europa. In China werden zijden stoffen, rijkelijk voorzien van goudbrokaat, in deze periode zeer hoog

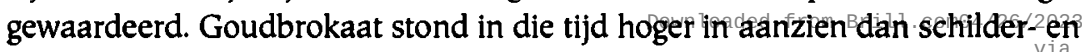




\section{Afbeelding 8 Fragment van een zijdeweefsel, damast, China, 14 $4^{\circ}-15^{\circ}$ eeuw (?), BK-NM-11931}

\section{Afbeelding 9}

Detail uit een maanfles, porselein, hoogte $45 \mathrm{~cm}$, China, begin $15^{\circ}$ eeuw, AK-RBK-1965-87

\section{Afbeelding 9 a}

Maanfles van afbeelding 9
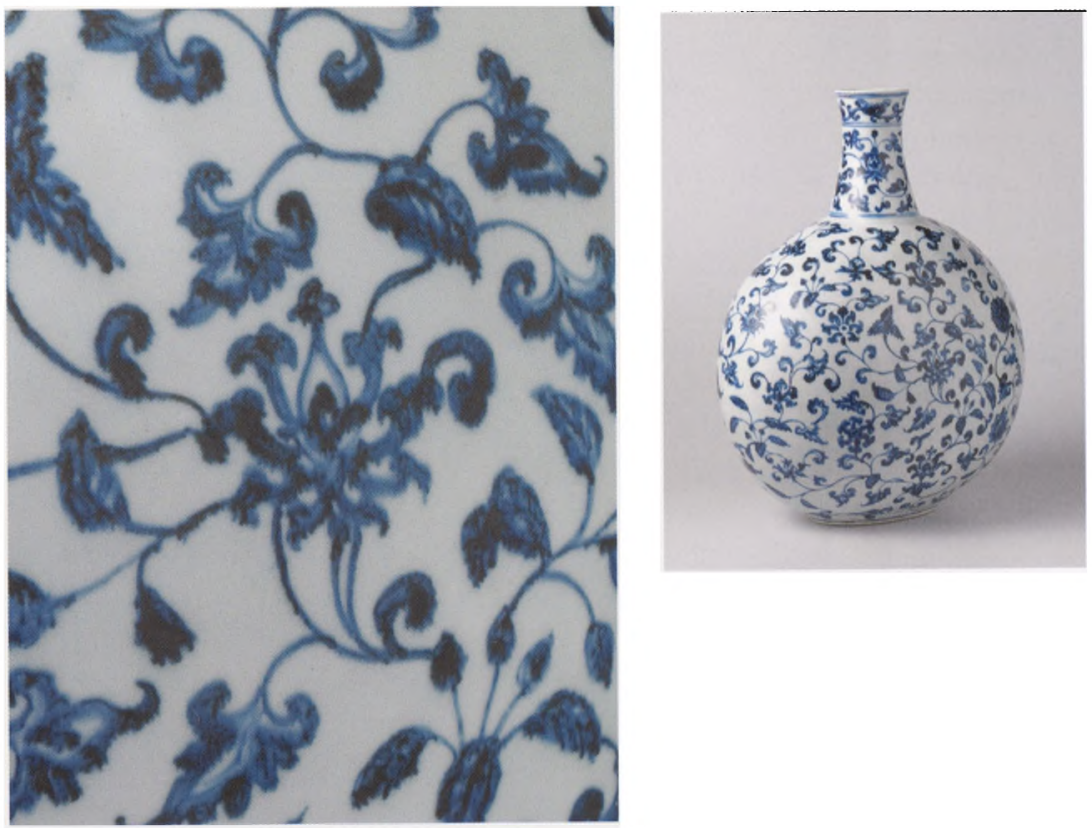

589) werden geïntroduceerd in China, eerst in architectuurornamenten en na die periode ook geleidelijk in de toegepaste kunsten. De slingerende lotusrank is dus voortgekomen uit een Westers motief, dat zich in China verder ontwikkeld heeft en vervolgens in Italië werd gekopieerd. ${ }^{17}$

\section{Chinese zijde voor Europa in de $17^{e}$ en $18^{e}$ eeuw}

De sprei van Lucia van Lilaar maakt deel uit van de luxe goederen die in de $17^{\mathrm{e}}$ en $18^{\mathrm{e}}$ eeuw vanuit Azië naar Nederland werden verscheept. Een van de drijfveren van de Nederlanders om aan het eind van de $16^{e}$ eeuw handel te $e_{\text {access }}$ 
gaan drijven in Azië vormden de berichten over de grote winsten die de Portugezen behaalden met de levering van Chinese zijde aan Japan. Zijde speelde dus bij de overwegingen van de in 1602 opgerichte VOC steeds een grote rol, al betekende dit niet dat het direct op grote schaal naar Europa werd verscheept. De belangrijkste component van de zijdehandel vormde de handel in ruwe zijde waarvan zowel in Japan als in Nederland garen werd vervaardigd (gereed) en vervolgens stoffen werden geweven. Deze handel in ruwe zijde blijft hier buiten beschouwing en de aandacht gaat juist uit naar de Chinese stoffen die Nederland bereikten.

Afbeelding 10 Fragment van een zijdeweefsel, China, Macao, circa 1600, BK-1997-13

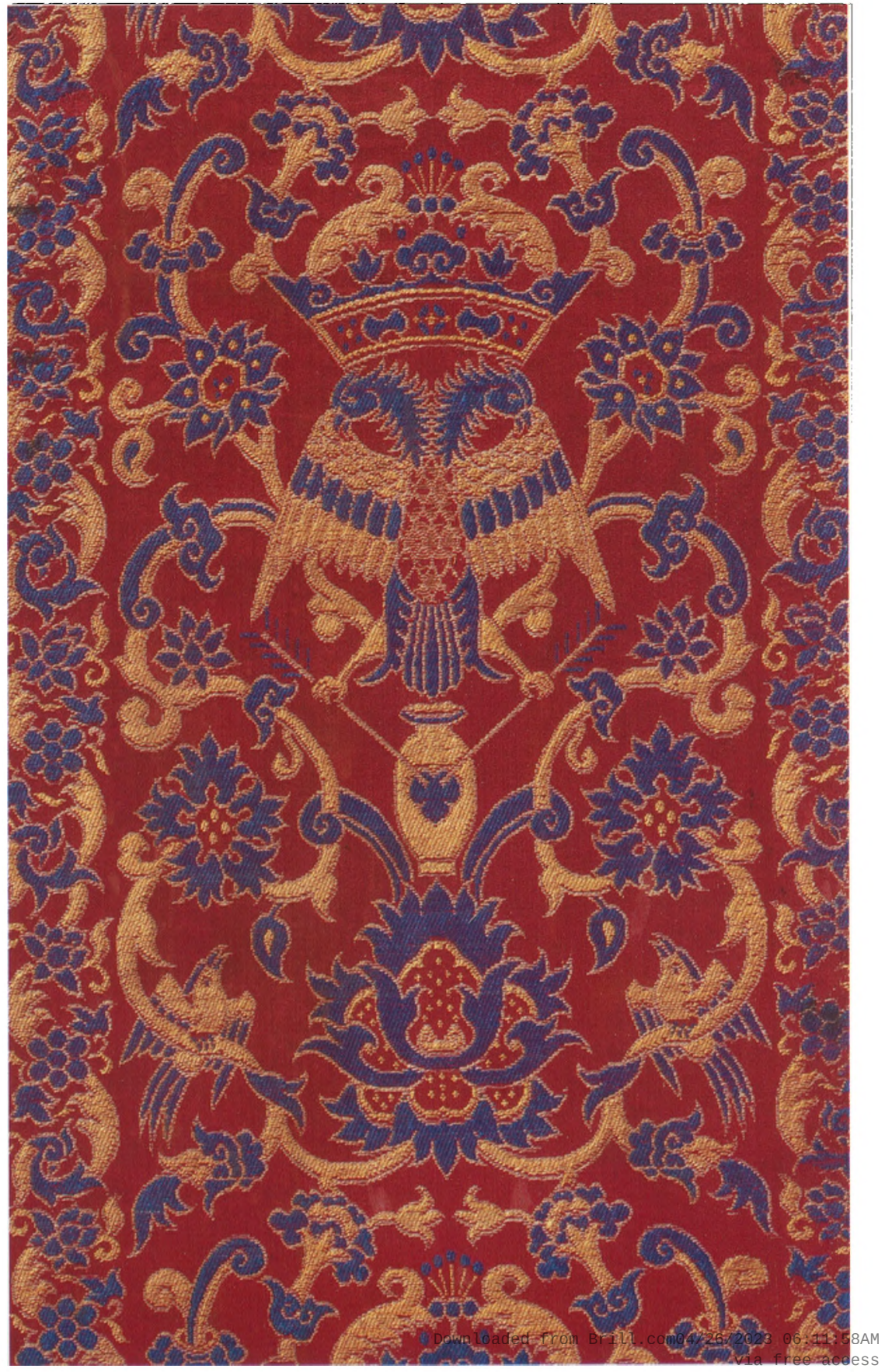


Naast de informatie over handelsmogelijkheden in Azië zelf, zorgden ook de luxe goederen die Portugese en Spaanse kooplieden in de $16^{e}$ eeuw in Europa invoerden voor enthousiasme. De zeldzaamheid en de kostbaarheid van lakwerk, porselein, maar ook van zijden stoffen vormden eveneens een stimulans voor de Nederlanders om zelf in Azië handel te gaan drijven. Afbeelding 10 toont een voorbeeld van een Chinees zijden weefsel uit dit vroege stadium van de directe handelscontacten tussen China en Europa. Fragmenten van identieke weefsels komen voor in verschillende Westerse collecties. ${ }^{18}$ Het is opvallend dat de Europese vormentaal in de motieven in dit fragment al duidelijk zijn terug te vinden. De gestileerde lotus kan als Chinees beschouwd worden, maar de opbouw van het ornament, met de omwonden bladstengels en de kroon boven de dubbele adelaar zijn volledig Europees. De dubbele adelaar zelf wordt wel in verband gebracht met de Habsburgers, maar het motief van de dubbelhoofdige vogel komt eveneens in Centraal-Azië voor. Ook in de vroegste periode van de directe handelscontacten over zee, toen het exotische karakter van de importen uit China zeer werd gewaardeerd, werd dus geëxperimenteerd met het verstrekken van voorbeelden waar de Chinese handwerkslieden naar moesten werken.

Behalve zijde naar Westers voorbeeld, werd ongetwijfeld zijde naar Europa verscheept die gewoon 'voor de markt' was gemaakt en niet speciaal op de wensen van de Europese kopers was toegesneden. Voor de Chinese zijdeproductie tijdens de Ming-dynastie was de streng gecontroleerde vervaardiging van weefsels voor het hof van groot belang. Er waren werkplaatsen in Peking en in de provincies ten zuiden van de Yangtze en daarnaast werd van particuliere ateliers gekocht. Zijden stoffen die uit deze periode zijn bewaard, zijn in allerhande technieken uitgevoerd en met uiteenlopende motieven gedecoreerd. Ook de formele bloemranken bleven bestaan als een voortzetting van de productie uit de $13^{\mathrm{e}}$ en $14^{\mathrm{e}}$ eeuw. De leidende smaak van het hof had zijn invloed op de gehele zijdeproductie en dus ook op de zijden stoffen die Europa bereikten. Rollen zijde werden bij uitstek gebruikt bij de uitwisseling van tribuutgeschenken, de Chinese opvatting van het handeldrijven met buitenlanders. ${ }^{19}$ Over de Chinese zijden stoffen in Nederland in de eerste helft van de $17^{\mathrm{e}}$ eeuw bestaat nog bijzonder weinig informatie. Gedocumenteerde stukken zijn onbekend. Uit verspreide gegevens in boedelbeschrijvingen is op te maken dat Aziatische stoffen (niet alleen Chinese) wel degelijk werden ingevoerd. ${ }^{20}$ Voor een deel waren het ongetwijfeld souvenirs en incidentele privé-leveringen door VOC-dienaren, maar ook de VOC zelf plaatste bestellingen. De Heren Zeventien vroegen in 1636 bijvoorbeeld om 'allerhande goede Chinese manufacturen' en uit protesten van de Nederlandse zijdereders tegen de toevloed van Aziatische zijden stoffen blijkt dat deze ook inderdaad geleverd werden. ${ }^{21}$

De burgeroorlog in China die voorafging aan de vestiging van de Qingdynastie (1644-1911), zorgde voor een onderbreking van de handel in Chinese zijden stoffen. Vanaf 1650 was alle uitvoer van Chinese producten voor een periode van dertig jaar zo goed als onmogelijk. De rust in China was rond 1680 weer teruggebracht en een gereguleerde handel overzee werd weer toegestaan. Voor de Chinese zijde-industrie betekende dit een voortzetting van productie uit de periode vóór de burgeroorlog. Dat Chinese zijde in Europa in de periode 1650-1680 schaars en kostbaar moet zijn geweest, blijkt wel uit het enthousiasme van de beschrijving van John Evelyn van de zijden $58 \mathrm{AM}$ 
kledingstukken die jezuïeten in 1664 met een schip van de Engelse East India Company vanuit China naar Londen brachten. ${ }^{22}$ De 'glorious vests' die hij zag, waren op dat moment een zeldzaamheid. De blijvende vraag, maar problematische levering van zijden stoffen in deze periode blijkt ook uit de verkoop van oude Chinese zijden stoffen aan Spaanse handelaren in de jaren 70 van de $17^{\mathrm{e}}$ eeuw. ${ }^{23}$

De vraag naar zijden stoffen, al dan niet geborduurd, groeide in China na de beëindiging van de burgeroorlog rond 1680 sterk door de opkomst van de middenklasse. Meer Chinezen konden zich luxueuze voorwerpen, waaronder zijden kleding en stoffen, permitteren. De productie groeide dus sowieso sterk en de vervaardiging van stoffen voor de Europese kopers maakte een onderdeel uit van deze totale groei. De hervatting van de handel op China ging in Europa gepaard met een sterke bloei van de belangstelling voor luxe Aziatische voorwerpen. Porselein werd in veel grotere aantallen dan voorheen in het interieur opgesteld, soms gecombineerd met spekstenen figuurtjes. Uit deze tijd stamt ook de grote voorliefde voor Chinees coromandellak, lakwerk met gesneden en vervolgens ingekleurde voorstellingen, waarvan de panelen gebruikt konden worden om wanden van kleine kamers te bekleden. In het interieur werd meer textiel gebruikt, waaronder Chinese zijde, waarbij soms beddenspreien, bedgordijnen, wandbekleding en gordijnen voor de vensters uit de zelfde stof werden vervaardigd. Ook voor deze periode zijn inboedelbeschrijvingen de belangrijkste bron van informatie over het gebruik van Chinese zijden stoffen in Nederland, maar wanneer de term 'Indiaans' wordt gebruikt, is het moeilijk vast te stellen wat precies werd bedoeld. Voor een deel zullen dit sitsen zijn geweest, beschilderde katoenen stoffen uit India, die aan het eind van de $17^{\mathrm{e}}$ eeuw in de mode kwamen als interieurstof, zoals de kraamkamer in het poppenhuis van Petronella Dunois uit 1676, dat zich tegenwoordig in het Rijksmuseum bevindt, laat zien. In enkele gevallen is echter duidelijk Chinese zijde bedoeld, zoals in het porseleinkabinet van Willem III aan het Binnenhof waar zich volgens een inventaris uit 1700 een 'blauw Oost Indisch satijn geborduurd in Chinese figuren en bloemen' bevond. ${ }^{24}$ Ook in het burgerlijke interieur werd Chinese zijde toegepast. Johan van der Marck, lid van de Leidse stadsregering, had volgens een boedelbeschrijving uit 1694 in zijn huis in de Breestraat in Leiden 'Chinees gefigureerde zijden behangsels', waarmee waarschijnlijk eveneens bedgordijnen zijn bedoeld. ${ }^{25}$ Lakenkoopman en rentenier Allard de la Court liet in 1719 een ledikant maken met 'blaauw Oostindies damast met geel oostindisch armosijn gevoerd, van binnen met blauw en van buyten met geel sij passement belegt'. ${ }^{26}$ Het is wel van belang te beseffen dat het merendeel van de interieurstoffen uit het eind van de $17^{\mathrm{e}}$ en het begin van de $18^{\mathrm{e}}$ eeuw Europees waren, Aziatische stoffen vormden een uitzondering. ${ }^{27}$

Gezien de kwetsbaarheid van het materiaal mogen we ons gelukkig prijzen dat enkele Chinees zijden ensembles uit deze periode de tand des tijds hebben doorstaan. Op de Menkemaborg in Uithuizen bevindt zich een hemelbed geheel bekleed met crèmekleurig zijden damast en voorzien van gordijnen in dezelfde stof. Het bed wordt genoemd in de boedelinventaris uit 1751, opgemaakt na het overlijden van Everdina Cunera van Berum en zal voor het overlijden van haar echtgenoot Unico Allard Alberda in 1714 zijn vervaardigd. ${ }^{28} \mathrm{De}$ ingeweven motieven zijn gestileerde bloemranken, geheel volgens de in Europa heersende smaak van het moment, want vergelijkbare 


\section{Afbeelding 11 \\ Fragment van een zijdeweefsel, damast, China, eind $177^{\circ}$ eeuw (?) BK-3765-B \\ Afbeelding 12 Detail uit een doopkleed van zijdedamast, China, begin $188^{\circ}$ eeuw, lengte $141 \mathrm{~cm}, \mathrm{BK}-1969-45-\mathrm{C}$ \\ Afbeelding 12a Doopkleed van afbeelding 12}
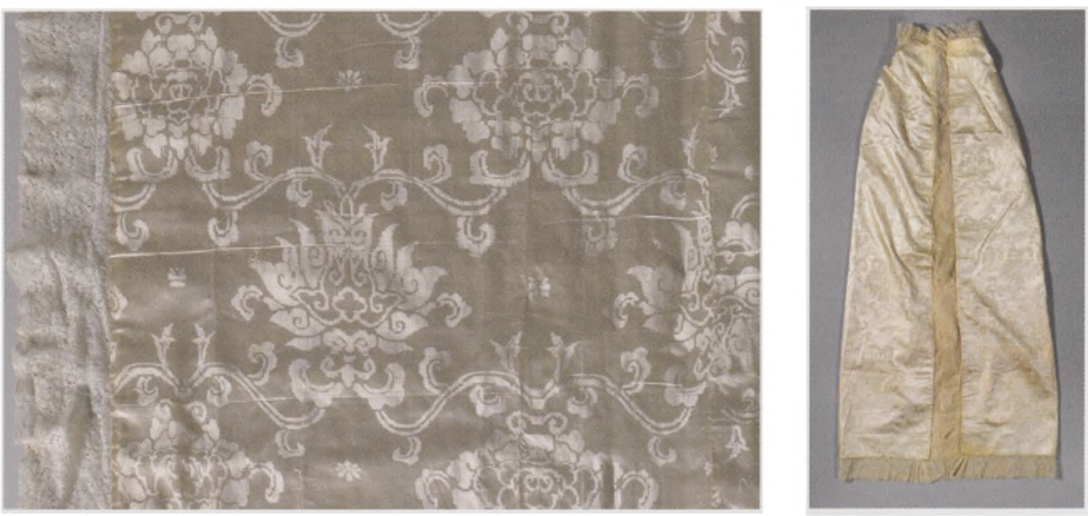

stoffen zijn terug te vinden in een Engels bed, in redelijk betrouwbaar te dateren kleding en in een interessante groep vaandels, vervaardigd uit Chinees zijdedamast, die in $\mathbf{1 7 0 0}$ door de Zweden op het Russische leger zijn buitgemaakt. ${ }^{29}$ In deze overgeleverde gedocumenteerde voorbeelden zijn het steeds ranken met gestileerde chrysanten, pioenen en lotussen. De motieven zijn vaak vrij klein. Bovendien hebben schering en inslag dezelfde kleur of slechts een klein kleurverschil, zodat de motieven enkel door speling van het licht zichtbaar zijn. De motieven zijn hierdoor minder nadrukkelijk dan in de weefsels uit de Ming-periode, maar toch is het duidelijk dat de productie na de burgeroorlog een voortzetting is van wat in de late Ming-tijd werd geweven. ${ }^{30}$

In de Rijksmuseumcollectie bevinden zich twee fragmenten uit deze periode. In het rode damast zijn de bloemen nog relatief groot en is het contrast tussen ketting en inslag vrij sterk (afb. 11). Dit krachtige patroon sluit aan op de smaak van de late Ming-tijd en zou om die reden aan het eind van de $17^{e}$ eeuw gedateerd kunnen worden. Op het crèmekleurige damast dat in een doopkleed is verwerkt, zijn de motieven van pioenen en lotussen iets kleiner, iets minder streng gestileerd en in een minder streng verband geordend (de bloemen lijken te zijn uitgestrooid) (afb. 12). De stof kan daardoor iets later, begin $18^{\mathrm{e}}$ eeuw, worden gedateerd. 


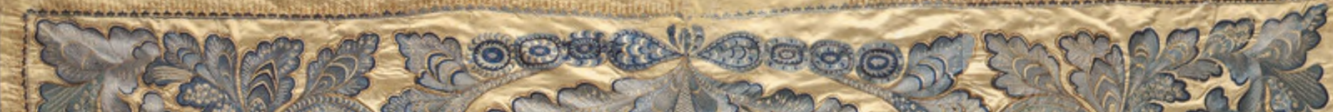

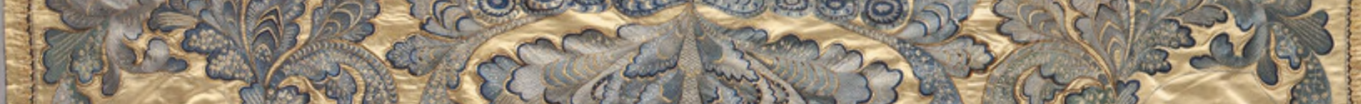

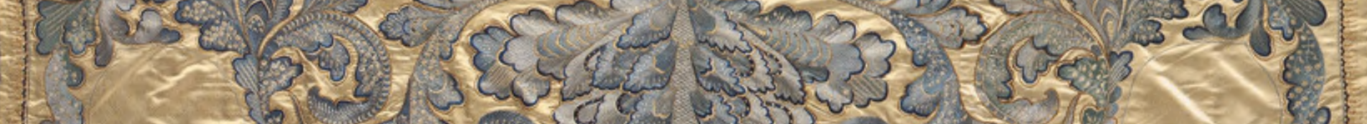

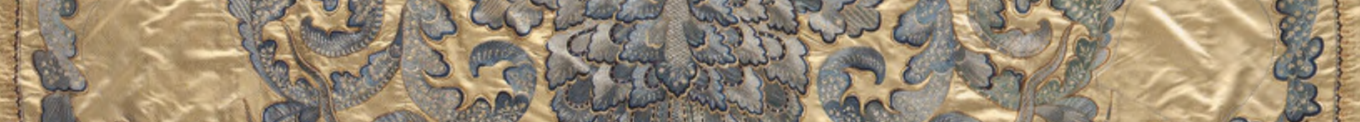

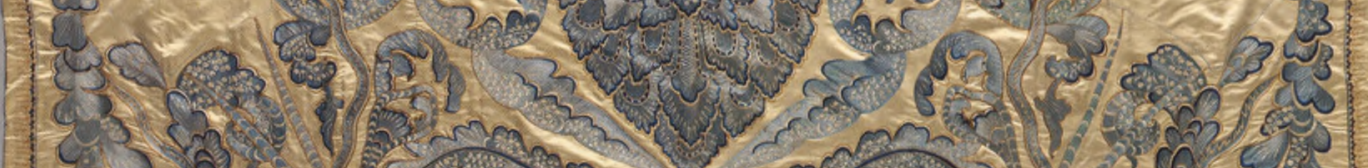

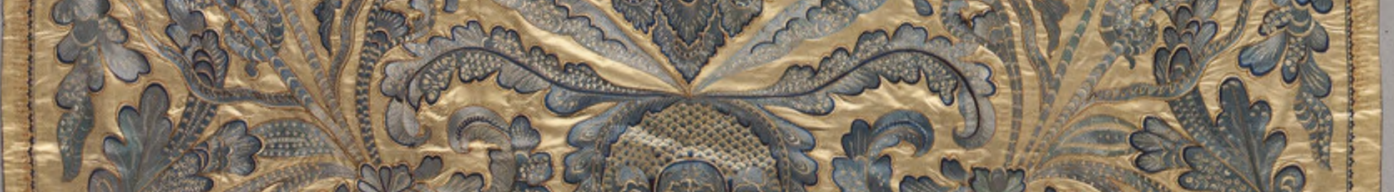

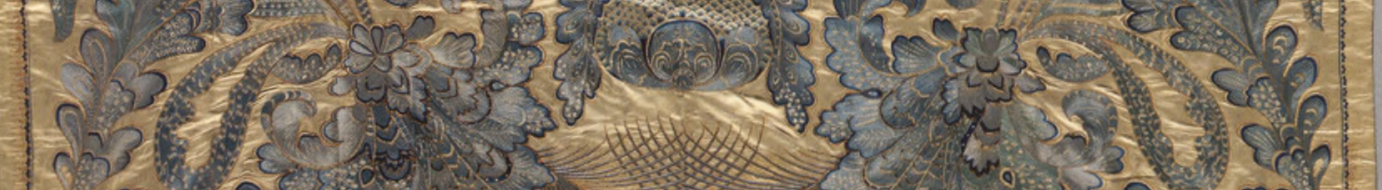

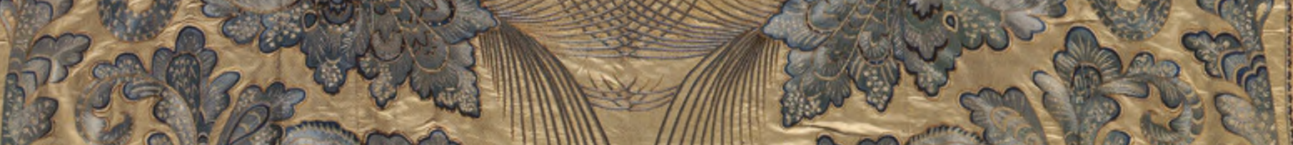
13 (3)

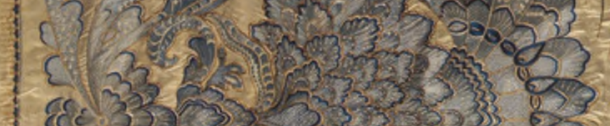

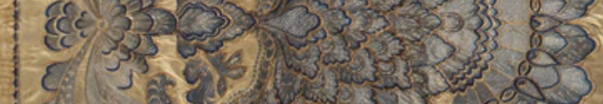

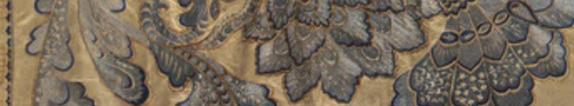

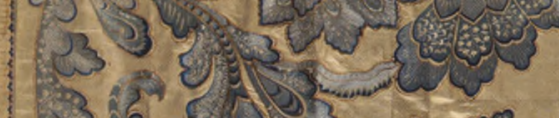

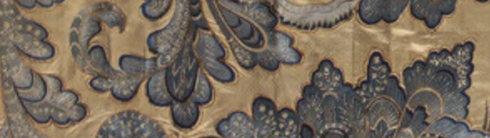

1.03 क है

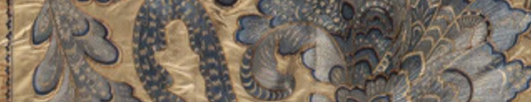

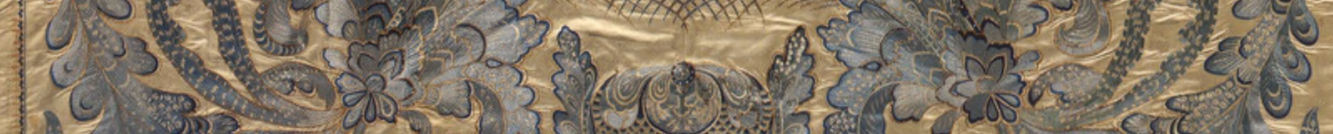

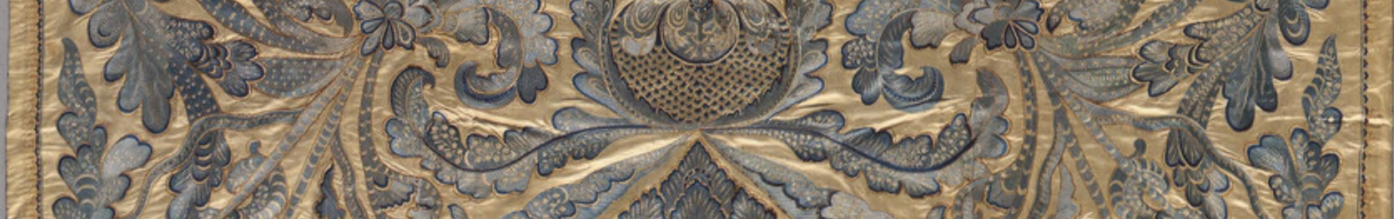

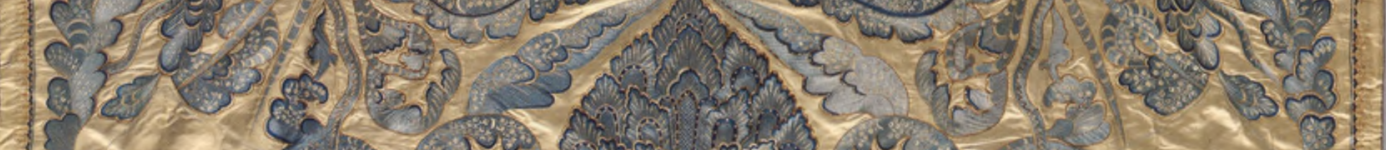
If

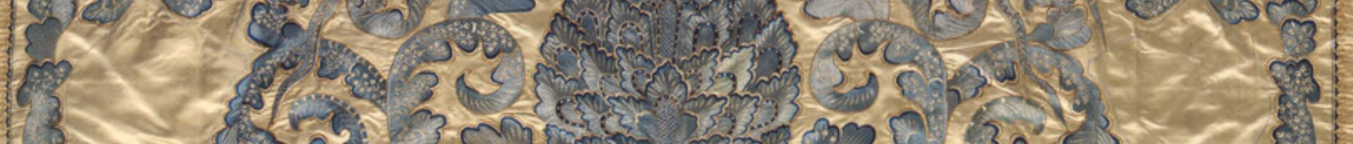

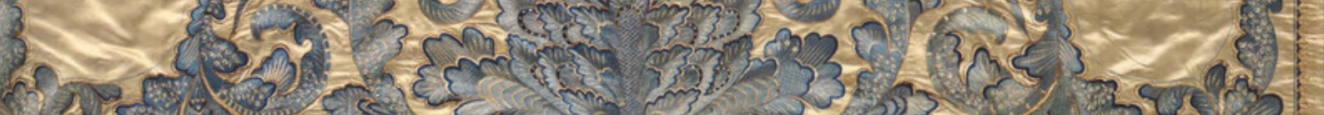

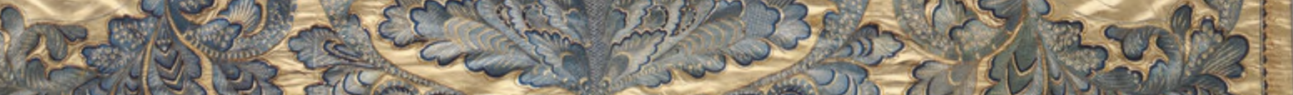

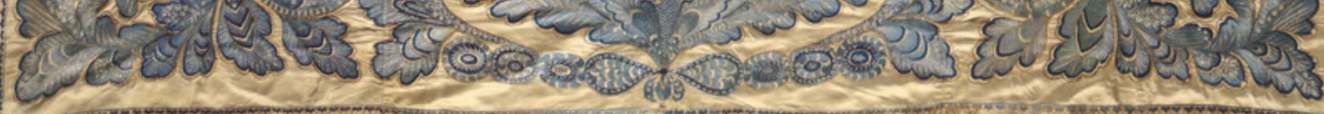




\section{Afbeelding 13} Sprei, geborduurde zijde, China, circa 1719, lengte $330 \mathrm{~cm}$, BK-1958-20-B
Afbeelding 14 Sprei, sits, India, Coromandelkust, 1720-1734, lengte $280 \mathrm{~cm}$, BK-1980-804

De VOC bestelde vanaf 1692 grote hoeveelheden Chinese zijden stoffen en streefde naar het monopolie op de import, maar ongetwijfeld hebben VOCdienaren het verbod om privé zijden stoffen in te voeren ontdoken. ${ }^{31}$ Van de bovenstaande damasten is niet bekend op welke manier ze in Nederland zijn ingevoerd. In de collectie van het Rijksmuseum bevindt zich echter een sprei waarover wel gegevens over de herkomst bekend zijn (afb. 13). Deze sprei is geen damast, maar rijk gedecoreerd met borduurwerk in blauw, zwart, wit en goud. $\mathrm{Zij}$ is afkomstig uit het Huis Rosendael en had een plaats op het belangrijkste staatsiebed van het huis, een bed dat zich tegenwoordig in het Rijksmuseum bevindt. ${ }^{32}$ In een inventaris uit 1764 wordt het bed met gordijnen van geschoren fluweel uiteraard genoemd evenals de 'oostindise geborduurde deeken, een sprey van wit satijn met blauwe en silvere blomme geborduurd, ook een oostindisch kleedie daar over leggende'. ${ }^{33}$ Gezien de datering van de sprei is het goed mogelijk dat deze aan het bed is toegevoegd door Petronella Wilhelmina van Hoorn (1698-1764). Petronella was in 1722 getrouwd met Lubert Adolf Torck (1687-1758) die Rosendael in 1721 erfde. Petronella was in de best denkbare positie om een dergelijke kostbaar bewerkte sprei uit China te ontvangen. Zij was de dochter van de gewezen gouverneur-generaal Joan van Hoorn (1653-1711) en haar grootvader, Willem van Outhoorn (1635-1720), was eveneens gouverneur-generaal in Indië geweest. Willem van Outhoorn bleef, in tegenstelling tot zijn zoon, tot zijn dood in Batavia wonen. Petronella en haar grootvader onderhielden een briefwisseling die gedeeltelijk bewaard is gebleven en waarin Van Outhoorn en Petronella regelmatig geschenken noemen, die Van Outhoorns brieven vergezellen. Een sprei wordt niet genoemd, maar in 1719 bedankt Petronella haar grootvader onder meer voor ' (...) curieuse gestikte bladen tot stoelkussens als mede het curieuse gestikte behangsel, alle twelke hun emploij zal genieten (...). ${ }^{34}$ Hiermee kan zeker deze sprei bedoeld zijn.

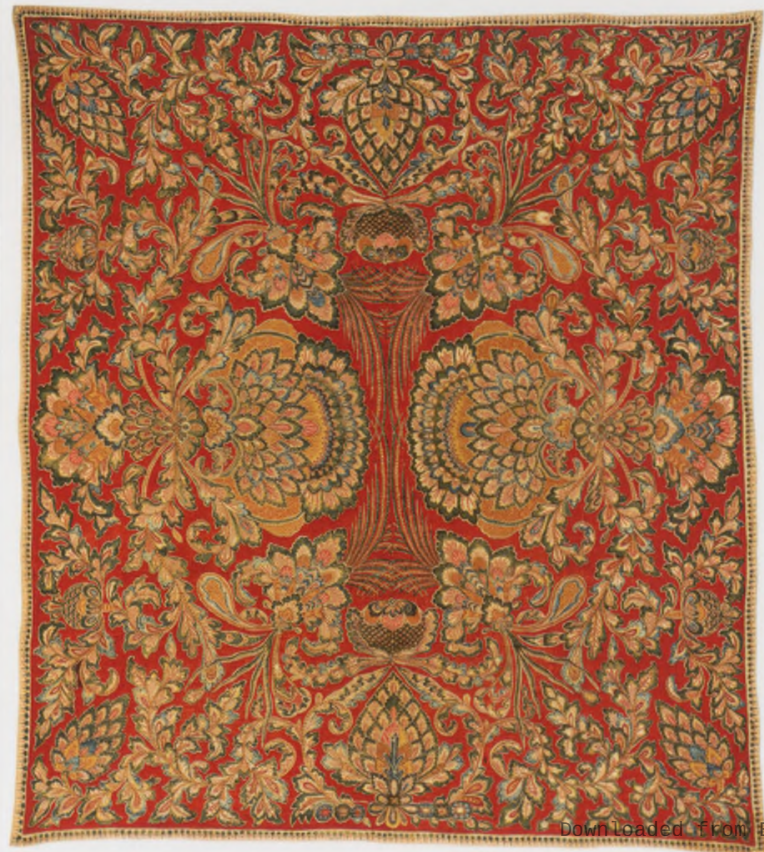


Het decor met grote bloempatronen komt sterk overeen met de beschildering van twee sitsen in de Rijksmuseumcollectie (afb. 14). Een daarvan is afkomstig uit kasteel Twickel en is aan te wijzen in een inventaris van $1736 .{ }^{35}$ Blijkbaar werden Nederlandse voorbeeldtekeningen zowel naar de Coromandelkust van India - waar de sitsen werden gemaakt - als naar China gestuurd of meegenomen. Een andere mogelijkheid is dat voorwerpen van China naar India (of omgekeerd) werden gestuurd als voorbeeld.

De grote bloemen van Petronella's sprei, gecombineerd met gestileerd ranken bladwerk die samen het gehele oppervlak vullen, maken een exotische indruk, maar blijken goed te passen in de Europese mode voor geweven zijden stoffen uit het tweede kwart van de $18^{\mathrm{e}}$ eeuw. Die mode is een duidelijk voorbeeld van chinoiserie: de vrije verwerking van Aziatische elementen tot een Europees, exotisch ogend product. De zijden stoffen werden vooral toegepast in kleding en in de Europese mode bestond steeds een grote vraag naar nieuwe patronen. De ontwikkeling is goed te volgen dankzij gedateerde ontwerpen en portretten waarop de geportretteerden kleding uit zijden stoffen dragen. In het tweede kwart van de $18^{\mathrm{e}}$ eeuw zijn de grote bloemen in de mode, soms nog gecombineerd met bandwerk met geometrische motieven die samen het hele oppervlak vullen. De toepassing van goud en zilver was geliefd. Op een portret uit het tweede kwart van de $18^{\mathbf{e}}$ eeuw draagt Clemens August (1700-1760), keurvorst en aartsbisschop van Keulen een banjan, een wijde huisjas, die door de motieven en de kleurstelling verwant is aan de sprei van Petronella (afb. 15). ${ }^{36}$ Het portret van Clemens August is opgenomen in de betimmering van lakpanelen en spiegels in het Indische kabinet van Falkenlust, het maison de plaisance van de vorst. De banjan en het Chinese kopje in zijn hand hebben een herkenbare Aziatische oorsprong. Door deze opvallende attributen en door de plaatsing van het portret presenteert Clemens August zich zonder meer als 'prins van het Oosten'. Het is opvallend dat de huisjas die hij voor deze gelegenheid heeft gedragen, van een

Afbeelding is Joseph Vivien, Clemens August, keurvorst en aartsbisschop van Keulen, Indisch kabinet Falkenlust, Brühl, 17201730. Uit: A Taste for the Exotic, zie noot 36

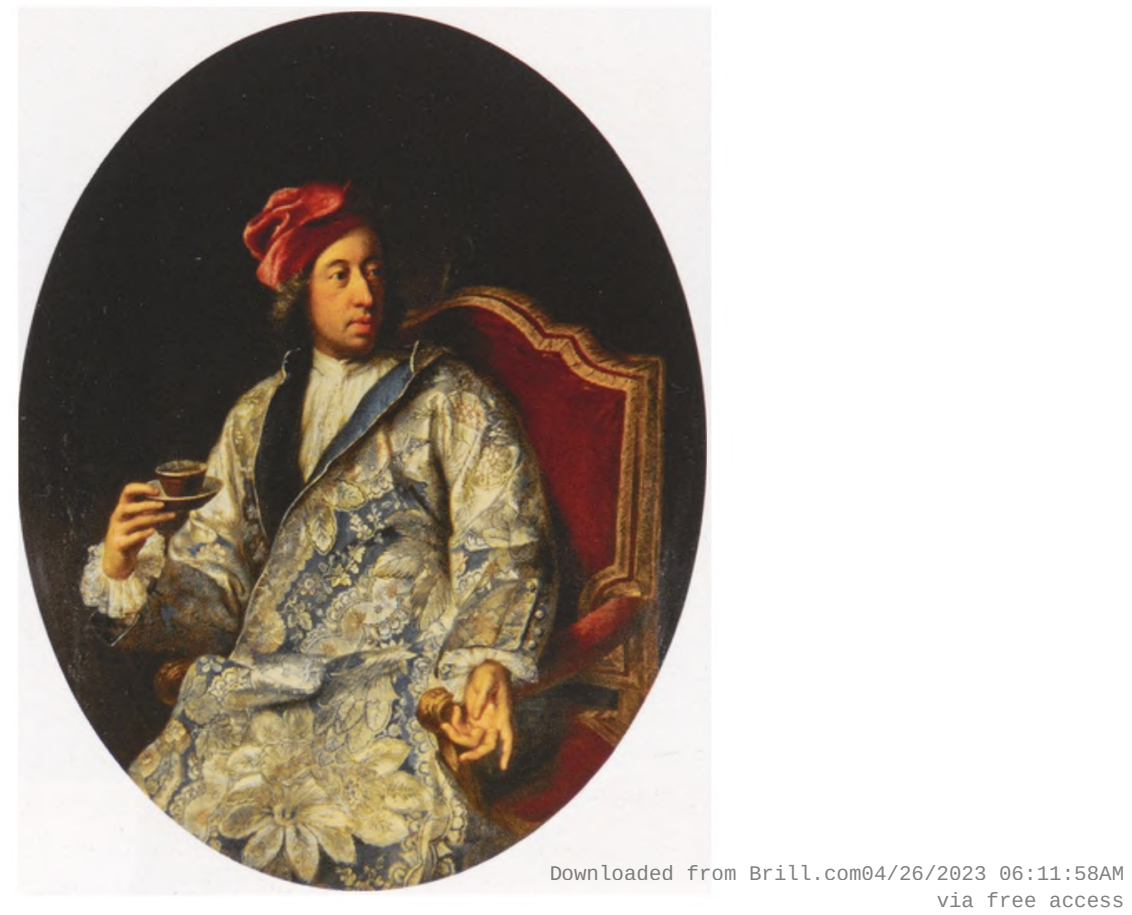




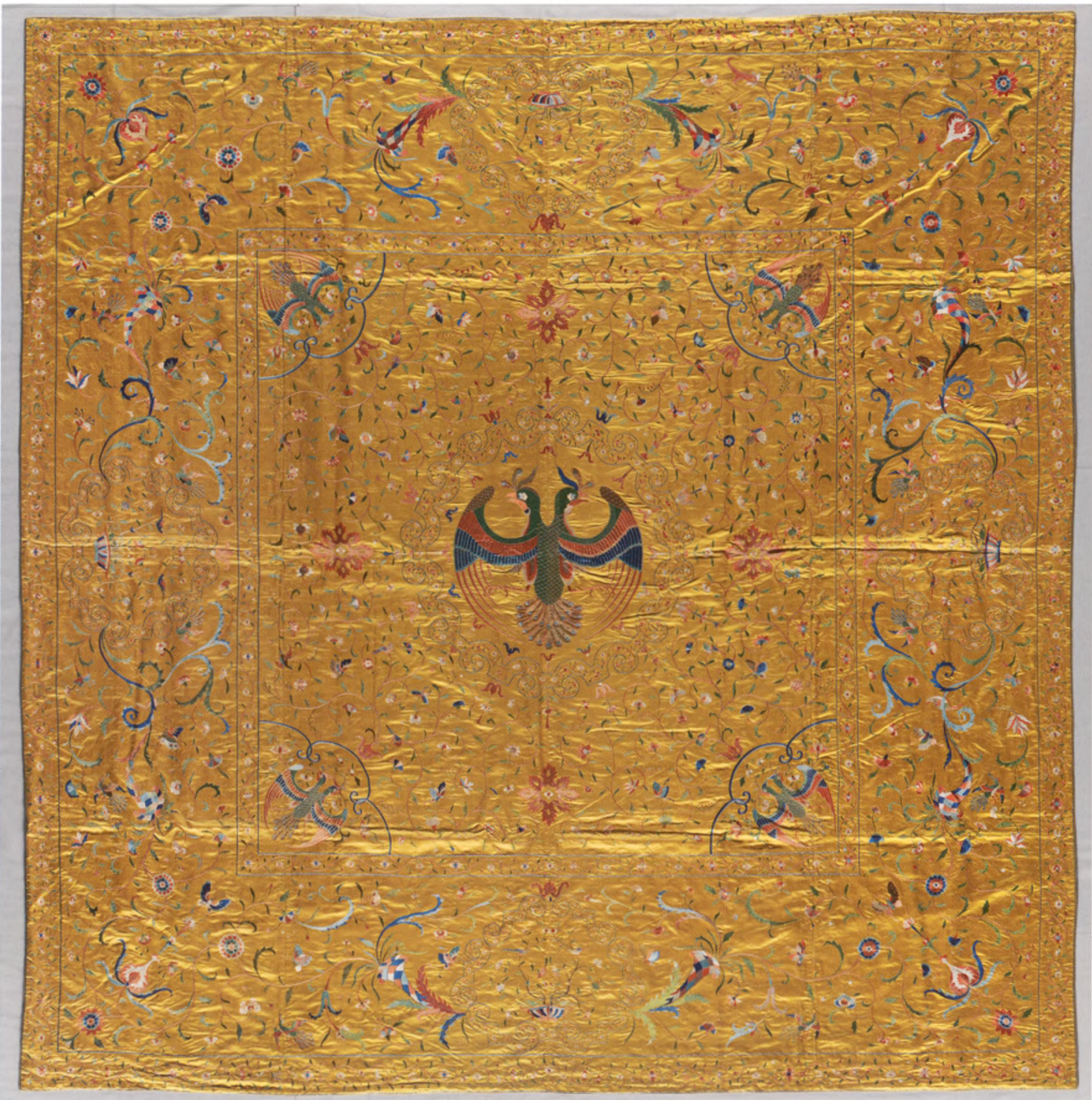

Afbeelding 16 Sprei, geborduurde zijde, China, tweede kwart $18^{\circ}$ eeuw, lengte $284 \mathrm{~cm}$, BK-1980-770-A
Europees chinoiserieweefsel was gemaakt, en niet van een 'echte' Aziatische stof. Europese chinoiserie voorwerpen voldeden blijkbaar beter om een bevredigend beeld van Azië op te roepen dan de Aziatische producten zelf. Petronella's Chinese sprei is een navolging van een dergelijk Europees chinoiserieweefsel, waarbij dus sprake is van de dubbele beïnvloeding: eerst is in Europa de chinoiseriezijde tot ontwikkeling gekomen onder invloed van de import van Aziatische producten en vervolgens diende de Europese verwerking daarvan als voorbeeld voor een Chinese geborduurde sprei en een Indiase sitsen deken. De techniek is overigens steeds verschillend: geweven in Europa, geschilderd in India en geborduurd in China.

Een ander voorbeeld van Chinees borduurwerk in de Rijksmuseumcollectie zijn de sprei en bedbehangsels afkomstig van kasteel Twickel (afb. 16). Op een gele ondergrond zijn weer met veelkleurige borduurgaren bloemranken aangebracht, nu in een vrij los verband, mét dalartussen enkele 06:11:58 AM 
vlinders. Het centrale motief op de sprei is een dubbelhoofdige pauw, een motief dat in de hoeken herhaald wordt. ${ }^{37}$ De toestand van de zijde is zo goed dat aangenomen wordt dat het niet of nauwelijks gebruikt is. Op stilistische gronden wordt het bed gedateerd in het tweede kwart van de $18^{\mathrm{e}}$ eeuw. Het kan een bestelling van Unico Willem van Wassenaer Obdam (16921766) zijn geweest, die in 1723 trouwde met Dononea van Goslinga.

De Chinese borduurders konden blijkbaar gemakkelijk voldoen aan de vragen van de Europese kooplieden. Enerzijds waren dat bestellingen waarbij

Afbeelding 17 Bed met bedgordijnen op een Chinees bord, porselein gedecoreerd in bleu poudré met in de velden famille verte, China, begin $18^{\circ}$ eeuw, diameter $39,8 \mathrm{~cm}$, AK-RBK-15844-A

Afbeelding 17a Bord van afbeelding 17

Afteelding 18 >> Fragment van een rol beschilderde zijde, China, 1770-1790, breedte $74,5 \mathrm{~cm}$, BK-1971-232 exact naar een voorbeeld werd gewerkt - zoals bij de sprei van Petronella was te zien, anderzijds lagen de smaak van Chinese en Europese kopers soms zo dicht bij elkaar dat Europese voorbeelden nauwelijks nodig waren. Ook in China zelf werden geborduurde bedgordijnen gebruikt. Al lang voor Europese kooplieden hun bestellingen plaatsten, werd in China borduurwerk gemaakt (afb. 17). ${ }^{38}$ In China waren professionele borduurders vooral mannen, maar dames borduurden thuis, deels als bijverdienste, deels als passende bezigheid, bijvoorbeeld voor een toekomstige bruid om haar geschiktheid als echtgenote te tonen. Wat betreft vorm en maten zijn de behangsels uit Twickel precies op bestelling gemaakt. De layout van de motieven en een deel van de motieven zelf zijn uitgevoerd naar Europees voorbeeld, maar het merendeel van de afzonderlijke motieven - bloemen, ranken, vlinders - werd eveneens toegepast in het borduurwerk voor de binnenlandse markt. ${ }^{39}$

De Europese en Chinese bloemmotieven hadden elkaar onderling al zo lang beïnvloed dat er in zekere zin sprake was van een universele bloemstijl, waarbij modieuze Europeanen zich niet bewust waren of de bloemen op hun
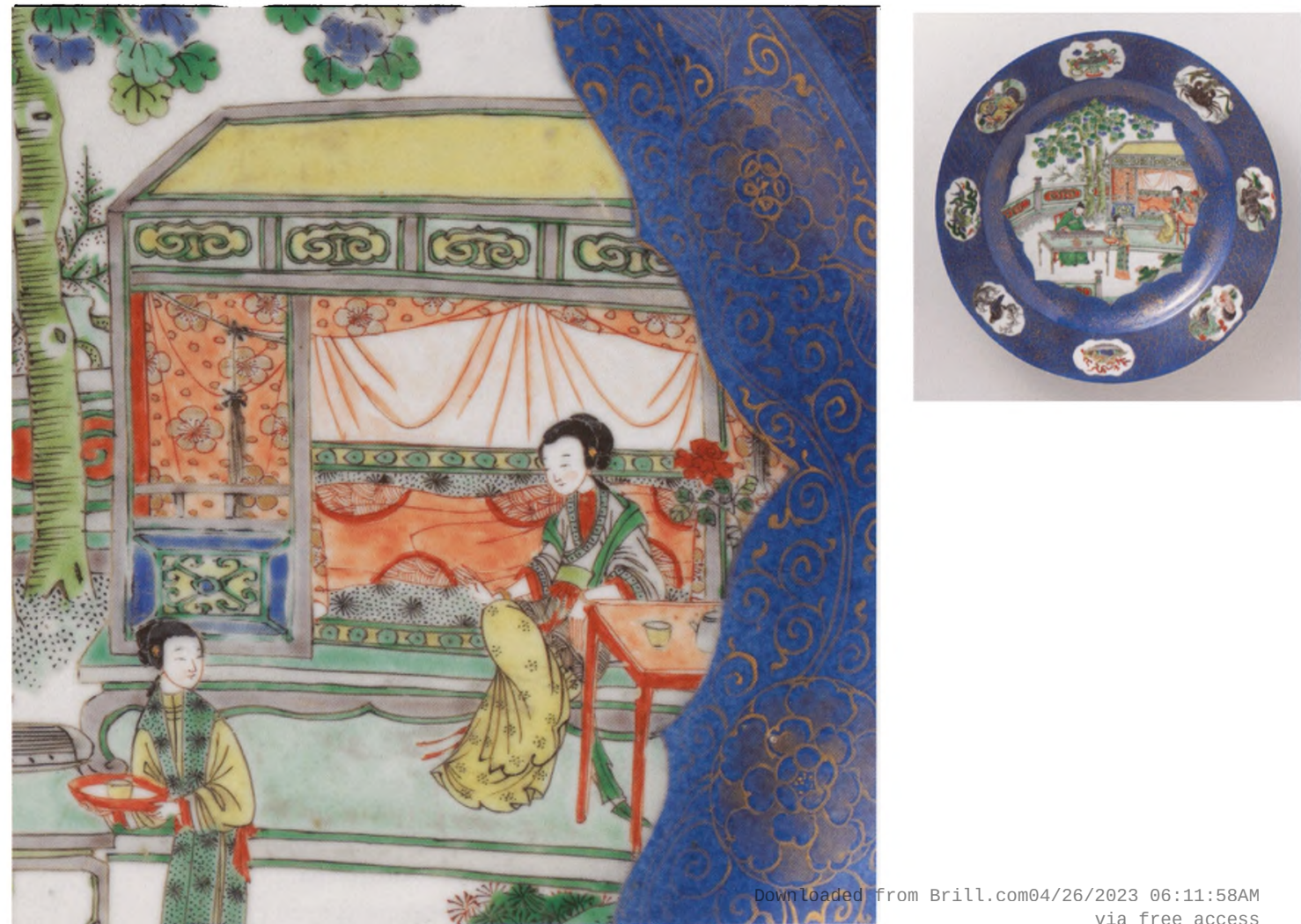

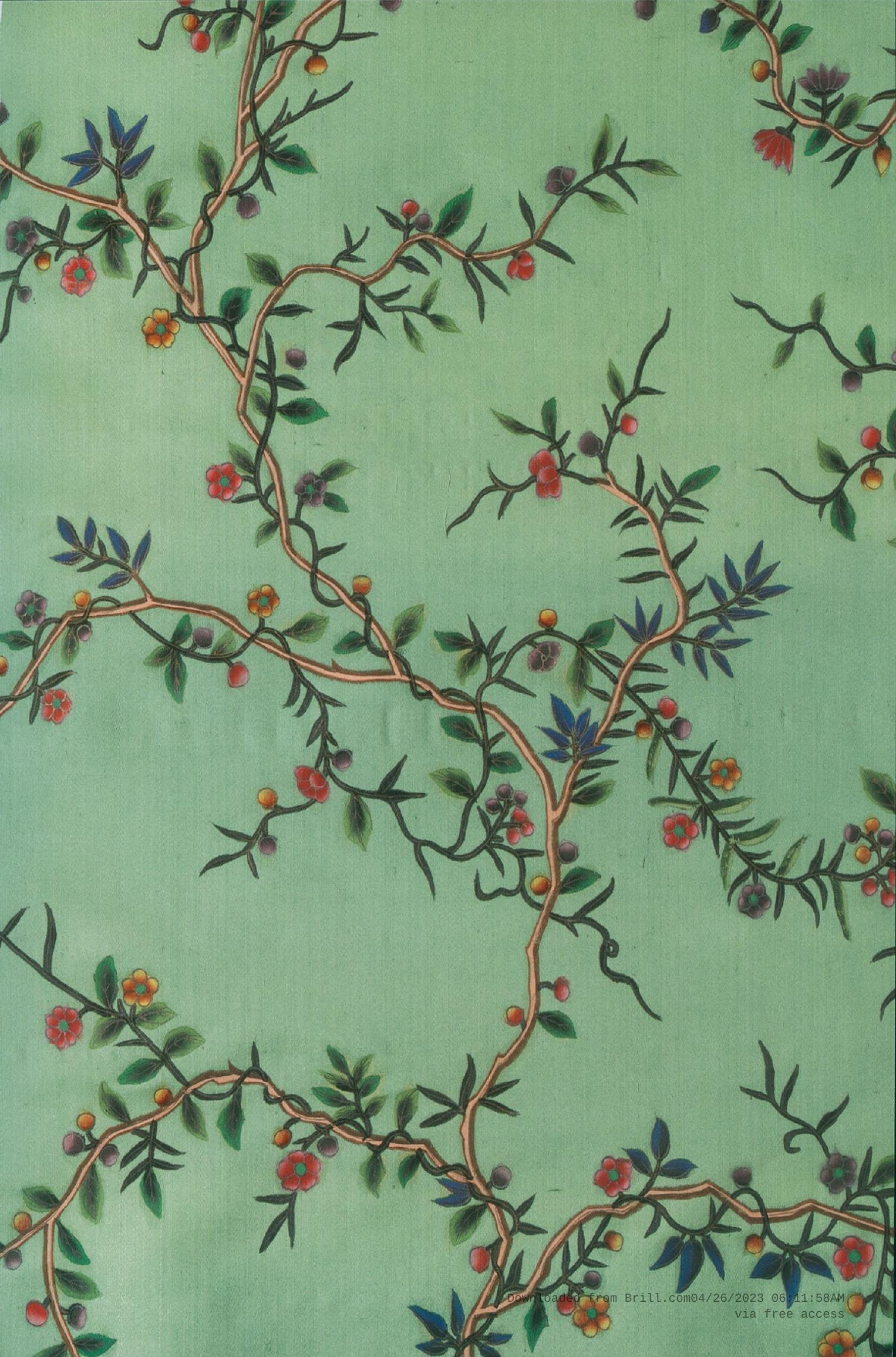
vest van oorsprong wellicht Indiaas of Chinees waren en daarin ook niet geïnteresseerd waren. In Europa waren geborduurde herenvesten in de $18^{\mathrm{e}}$ eeuw een grote mode. ${ }^{40}$ Elegante heren konden in Parijs rond 1780 wel 300 vesten hebben. Een deel daarvan werd ongedecoreerd naar China gebracht en daar van geborduurde bloemen voorzien. ${ }^{41}$ Niet om een extra exotisch vest te verkrijgen, maar omdat Chinezen de universele ChineesEuropese bloemmotieven goedkoper konden borduren dan hun collega's in Parijs en vrijwel even goed.

Borduren is een buitengewoon arbeidsintensieve decoratietechniek. Een goedkoper alternatief was het beschilderen van zijde. ${ }^{42}$ Zijde werd beschilderd in werkplaatsen die vooral papieren behangsels maakten, vanaf 1700 mondjesmaat en na circa 1760 op grote schaal. De beschilderde motieven en de manier van werken komen overeen. Met inkt werd een patroon op de zijden stof getekend, eventueel kon een ingeïnkte tekening op de stof worden afgedrukt om het patroon over te brengen. Vervolgens werden de kleuren aangebracht en werden contouren soms geaccentueerd met goud en zilver. Deze beschilderde zijden stoffen werden gebruikt als wandbespanning. In het Rijksmuseum bevindt zich een rol groene zijden bespanningstof, beschilderd met bloeiende bloemtakken (afb. 18). Kenmerkend voor de Chinese herkomst van de zijde is de breedte van de stof van $74,5 \mathrm{~cm}$. (Europese zijden stoffen zijn meestal tussen de 50 en $60 \mathrm{~cm}$. breed) en ook de zachtheid en de glans. Deze werden verkregen door de stof met was te bewerken. ${ }^{43}$

De rol is aan een van de uiteinden voorzien van een raadselachtige inscriptie, waarin de in Japans schrift geschreven Japanse naam Nononu opvalt. ${ }^{44}$ Lezing en vertaling zijn problematisch, maar een deel van de inscriptie kan gelezen worden als 'gemaakt door Nononu.' Voor Japanners was het niet mogelijk in China te werken, toch is het typisch Chinees werk voor de Europese markt. De rol van Nononu blijft vooralsnog onduidelijk. Aan dergelijke inscripties werd in Europa in de $18^{\mathrm{e}}$ eeuw wel degelijk waarde gehecht. Verschillende Europese zijden weefsels in Aziatische stijl hebben meegeweven pseudo-inscripties in de rand. ${ }^{45}$

Lucia van Lilaars gele beddensprei past in de stroom van Chinese luxegoederen die Nederland in de $18^{\mathrm{e}}$ eeuw bereikten. Door de langdurige en intensieve contacten tussen China en het Westen was het voor haar vooral een luxueus en niet zo zeer een exotisch product. De Chinezen hadden geleerd in te spelen op de wensen van de Europeanen, en tegelijkertijd had de aanwezigheid van Aziatische producten vanaf het eind van de $16^{\mathrm{e}}$ eeuw, sporadisch zelfs al eerder, de mode in Europa beïnvloed. Europa had zich de Aziatische importen geheel eigen gemaakt. De sprei werd na Lucia's dood niet als Chinees omschreven, maar als geel - dat was blijkbaar het meest kenmerkende element. De spreien van Lucia van Lilaar en Petronella van Hoorn laten zien hoe de onderlinge beïnvloeding van China en het Westen in zijde tot uitdrukking kon komen. Uliteindelijk drong het Chinese borduurwerk van Lucia van Lilaar het verste in de Westerse culturele traditie door: rond de schouders van een priester in een Amersfoortse parochie. 
1. Tussen 1963 en 1971 gaf hij een groot aantal voorwerpen, vooral kerkelijk zilver in bruikleen aan het Rijksmuseum die later deels gekocht zijn en deels geretourneerd. De kazuifel met toebehoren was van 1959 tot 1960 in bruikleen in het Aartsbisschoppelijk Museum in Utrecht (onder nummer ABM t02317a-e), vriendelijke mededeling Arno van Os, Museum Catharijneconvent, Utrecht.

2. Uit het Dagboek van Frans Zand en Maria Elleboog 1630-1980, Amersfoort, 1980, p. 20.

3. Noch in de papieren over de nalatenschap van Lucia van Lilaar (boedelbeschr., notaris H.A. Vlieckx, 28-01-1819, archief Eemland, AT.056-a-011 rep 11 (Stoutenburg) en rep 31 (stadshuis)) noch in het archief van de Xaveriuskerk (archief Eemland, archief parochie St. Franciscus Xaverius) is iets te vinden over een schenking van zijden stof voor een set paramenten, of over de vervaardiging daarvan. Uit bezitslijsten van de Sint Franciscus Xaveriusparochie blijkt dat rond 1900 al geen kazuifel van gele Chinese zijde meer aanwezig is (inv.nrs. 147 en 226). Er worden 28 andere kazuifels genoemd in verschillende kleuren, maar geen gele.

4. Andere verwervingen van Van Harten zijn wel in het parochie-archief terug te vinden. Van Harten zelf is overleden en zijn nazaten beschikten niet over enige informatie over de herkomst van de paramenten.

5. L. van Burgsteden, Kasteel Stoutenburg rond 1800; erfenis van Lucia van Lilaar, Leusden, 2007.

6. Van Burgsteden, Op.cit. (noot 5), p. 76.

7. Kerkrekeningen en kasboeken archief parochie St. Franciscus Xaverius, inv.nr. 274.

8. Uit het dagboek, Op.cit. (noot 2), p. 24.

9. V. Wilson, Chinese Textiles (Victoria \& Albert Museum, Far Eastern Series), Londen, 2005, p. 31, afb. 29; C.J.A. Jörg, 'Vergane Glorie; Chinese zijden stoffen in het Nederlandse interieur in de achttiende eeuw', in: A. Ouwerkerk (red.), Het Nederlandse Binnenhuis gaat zich te buiten; internationale invloeden op de Nederlandse wooncultuur (Leids Kunsthistorisch Jaarboek 14), Leiden, 2007, p. 184, afb. 4 (groen fond); A. Geyer, Oriental Textiles in Sweden, Kopenhagen, 1951, nr. 128 (wit fond). De spreien hadden een formaat van 200 aे $250 \mathrm{~cm}$ in het vierkant. Een geborduurde sprei afgebeeld op een schilderij van Jan van der Heyden uit 1712 zal een vroeg voorbeeld zijn van de import van deze producten. Zie E. Hartkamp-Jonxis, 'Prachtige vrachten; exotisch textiel in Nederland', Antiek 31/9 (april 1997), afb. 14.

10. Tuuk Stam en René van Blerk meenden gladgestreken plooien te herkennen op de bursa, hetgeen gebruik van de stof in een jurk naar hun idee aannemelijk zou maken. Dit zijn geen gladgestreken plooien, maar slijtsporen veroorzaakt door diagonaal gespannen draden onder de gele zijde, draden waarmee de stof strak om een kartonnen rechthoek is gespannen. Zie T. Stam en R. van Blerk, 'Borduurkunst uit China', Aziatische Kunst 25/2 (1995), pp. 2-26, daar p. 22.

11. Het parochet wordt bewaard in Museum Fléhite, in bruikleen van de Joodse Gemeente van Amersfoort. Zie E. Hartkamp-Jonxis, 'De voorhang van de synagoge in Amersfoort of een japon van Wilhelmina van Pruisen', Achttiende-eeuwse kunst in de Nederlanden (Leids Kunsthistorisch Jaarboek 4 (1985)), Delft, 1987, pp. 401-414.

12. Stam en Van Blerk, Op.cit. (noot 10), p. 21. N. de Bisscop, De Chinese Verleiding; Chinese exportkunst van de zestiende tot de negentiende eeuw (tent.cat. Kunsthal SintPietersabdij), Gent, 2009, nr. 6.78, p. 227 voor een op het wapen na identiek exemplaar in Carolus Borromeuskerk, Antwerpen.

13. J.C.Y. Watt e.a., When Silk was Gold; Central Asian and Chinese textiles (cat. Cleveland Museum of Art / Metropolitan Museum of Art), New York, 1997, p. 5. 14. Watt, Op.cit. (noot 13), p. 128.

15. Watt, Op.cit. (noot 13), pp. 15-18. In het midden van de $14^{e}$ eeuw kwam er een eind aan de macht van de Mongolen. De export verminderde. Tijdens de Yongleperiode (1403-1424) was handel nog mogelijk, maar daarna nam de buitenlandse handel sterk af. 
16. Dijon, Musée des Beaux Arts.

17. J. Rawson, Chinese ornament; the lotus and the dragon, New York, 1990. Het hele boek gaat over dit onderwerp, voor een overzicht, zie p. 14.

18. B. Markowsky, Europäische Seidengewebe des 13.-18. Jahrhunderts (cat. Kunstgewerbemuseum der Stadt Köln), Keulen, 1976, cat.nr. 729.

19. Wills geeft en overzicht van geschenken aan de ambassadeurs Pieter van Hoorn (1666-1668), Manoel de Saldanha (1667-1670), Bento Pereira de Faria (1678) en Vincent Paats (1685-1687). Zij krijgen vooral rollen zijde en zilveren munten.

Zie J.E. Wills Jr., Embassies and Illusions, Dutch and Portuguese envoys to K'ang Hsi, 1666-1687, Cambridge (Mass.), 1984, p. 249.

20. Inventarissen van de Oranjes uit 1619 en 1632, zie Hartkamp-Jonxis, Op.cit. (noot 9), p. 409. Loet Schledorn geeft een fraai en vroeg voorbeeld van de toezending van Chinese zijde. Pieter Walchsz. uit Delft verblijft in 1601 in Pattani en stuurt zijn broer 'een stucxken blauwe sijde van China'. Zie L. Schledorn, 'De Kamer Delft van de VOC: een rijke bron', in: E. Bergvelt e.a. (red.), Burgers verzamelen, 1600-1750; schatten in Delft, Zwolle/Delft, 2002, p. 31. De toepassing van stoffen in het interieur begon in deze periode. Het bood een betere mogelijkheid een eenheid te creëren dan bijvoorbeeld met wandtapijten het geval was. Amalia van Solms was een van de eersten die met behulp van textiel streefde naar eenheid in het interieur en uit beschrijvingen van haar vertrekken blijkt dat zij soms ook Aziatische stoffen koos.

Zo bevonden zich in de bedkamer in Huis ten Bosch banen 'zwart Indiaans damast'.

C.W. Fock (red.), Het Nederlandse interieur in beeld 1600-1900, Zwolle, 2001, p. 101.

21. Hartkamp-Jonxis, Op.cit. (noot 9), p. 413.

22. M. Jourdain en R. Soame Jenyns, Chinese Export Art; in the eighteenth century, Feltham, 1967, p. 64. Dagboeknotitie 22 jan. 1664.

23. R. van Blerk, Weef- en Borduurkunst uit China (doctoraalscriptie Universiteit Utrecht), Utrecht, z.j. , pp. 40-41.

24. Hartkamp-Jonxis, Op.cit. (noot 9), p. 415.

25. Fock, Op.cit. (noot 20), p. 105.

26. Fock, Op.cit. (noot 20), p. 196.

27. Voor interieurdamast, zie C. Browne, 'Silk Damask Bed Furnishings in the Early Eighteenth Century - Influences on Choice in Colour and Design', in: A. Jolly (red.), Furnishing Textlles; studies on seventeenth-and eighteenth-century interior decoration (Riggisberger Berichte 17), Riggisberg, 2009, pp. 47-58.

28. Jörg, Op.cit. (noot 9), pp. 181-182. De omschrijving is overigens ' 1 ledicant met geel behangsel', zonder vermelding van de Chinese herkomst. Reden te meer om de vermelding van een 'geel zijde sprey' van Lucia van Lilaar in verband te brengen met de stof voor de kazuifel.

29. In een bed in Melville House (Engeland) uit circa 1700 zijn twee soorten damast gebruikt. Volgens Wilson zijn de kleine meanderende ranken en bloemen puur Chinees, de grotere, meer gestileerde bloemen aangepast aan de Europese smaak, zie V. Wilson, 'The ivory damask bed curtains', Transactions of the Oriental ceramic Society 66 (2001-2002), pp. 111-112. Kledingstukken, die niet voortdurend aan het licht zijn blootgesteld, hebben een grotere kans te overleven dan interieurstoffen. De kleren van poppen die Lord and Lady Clapham voorstellen, dateren uit 1690-1700 en zijn gemaakt van vergelijkbare damast, zie Wilson, Op.cit. (noot 9), p. 23. Voor andere gedocumenteerde kledingstukken uit Chinese zijde, zie Rothstein, 'Silks for the American market', Connoisseur 166 (1967), pp. 90-94. Jörg geeft een overzicht van gedocumenteerde bedden met Chinese zijde (Jörg, Op.cit. (noot 9) p. 182 en noot 14).

30. S. Vainker, Chinese Silk; a cultural history, New Brunswick, 2004, p. 173.

31. Jörg geeft een voorbeeld van een privé bestelling: de in 1768 in Kanton overleden assistent François Hélène van Eymbeek had een privéschuld aan borduurwerker Pinqua, zie Jörg, Op.cit. (noot 9), p. 195.

32. Inv.nr. BK-1958-20-A.

33. J.C. Bierens de Haan, Rosendael, groen hemeltjen op aerd; kasteel, tuinen en bewoners sedert 1579, Zutphen, 1994, p. 127. 
34. Bierens de Haan, Op.cit. (noot 33), p. 86. Het lijkt, gezien de datering, niet waarschijnlijk dat ze in 1709 met Joan en Petronella meekwamen, toen zij vanuit Batavia repatrieerden. Om diezelfde reden is het minder waarschijnlijk dat er een verband bestaat met de vermelding van Chinese spreien in de boedelbeschrijving van Petronella's vader, Joan van Hoorn - 'dry geborduurde Chinese spreyen' - die in 1711 overleed. Vriendelijke mededeling Bea Brommer.

35. E. Hartkamp-Jonxis, Sitsen uit India/Indian Chintzes, Amsterdam/Zwolle, 1994, nr. 15. Andere sitsen met een sterk gelijkend decor: Rijksmuseum, inv.nr. BK-195326, V\&A, inv.nr. IS17-1976.

36. Anna Jolly dateert het schilderij 1722-1725 (inleiding in A. Jolly (red.), A Taste for the Exotic; foreign influences on Early Eighteenth-centurty Silk Designs (Riggisberger Berichte 14), Riggisberg, 2007. In andere publicaties: 1731.

37. Voor een vergelijkbare sprei, zie D.S. Howard e.a., A Tale of Three Cities; Canton, Shanghai and Hong Kong; three centuries of Sino-British trade and decorative arts, Londen, 1997, cat.nr. 211 (particuliere collectie Engeland); een sprei met een centrale dubbelhoofdige vogel, maar nu eerder een adelaar, bevindt zich in de Hermitage,

T. Arapova e.a., Chinese export art in the Hermitage Museum; late $16^{\text {th }}-19^{\text {th }}$ centuries (tent.cat. Hermitage), Sint Petersburg, 2003, cat.nr. 180.

38. Watt, Op.cit. (noot 13), cat.nr. 50, $\left(11^{\mathrm{e}}-13^{\mathrm{e}}\right.$ eeuw).

39. Vainker, Op.cit. (noot 30), p. 160; V. Wilson, Chinese Dress (Victoria and Albert Museum, Far Eastern Series), Londen, 1986, p. 105.

40. N. Scheuer, 'The elegant art of embroidery', An Elegant Art; fashion \& fantasy in the eighteenth century (tent.cat. Los Angeles County Museum), Los Angeles/New York, 1983, p. 103.

41. Scheuer, Op.cit. (noot 40), p. 97. Dit werd door een tijdgenoot opgemerkt: C. de Saint Aubin, de grootste borduurder van Frankrijk in de $18^{e}$ eeuw in zijn boek the Art of the embroider uit 1770 .

42. A. Jolly, 'Painted silks from China; problems of attribution and dating', in: A. Jolly (red.), Furnishing Textiles; studies on seventeenth- and eighteenth-century interior decoration (Riggisberger Berichte 17), Riggisberg, 2009, pp. 167-168.

43. Jörg, Op.cit. (noot 9), pp. 205-206, noot 28 beschrijft het proces: vellen papier gedrenkt in was werden op de stof gelegd, het geheel werd stijf opgerold rond een houten stok en aangedrukt. De groene rol van het Rijksmuseum is gewikkeld rond een platte houten kern. Deze speelde volgens Jörg wellicht een rol in dit proces.

44. De karakters kunnen als volgt gelezen worden: 'pijnboom, kastanje en voorspoed' (een aanduiding van het patroon?), '45, naam hand', 'Nononu 37'. De getallen zijn geschreven in een 'volks' Chinees schrift. 'Naam hand' kan geïnterpreteerd worden als gemaakt door. Vriendelijke mededeling Ellen Uitzinger. Volgens Menno Fitski is Nononu een Japanse naam. Jörg vermeldt inscripties op zijde, waarschijnlijk de vaststelling van verschillende investeringen in de levering van zijde. Zie Jörg, Op.cit. (noot 9), noot 33.

45. Anna Jolly bespreekt Europese chinoiseriezijde met ingeweven pseudo-inscripties en geeft ook een aantal voorbeelden van Chinese inscripties in haar artikel 'A Group of Chinese Chinoiserie silks', in Jolly, Op.cit. (noot 36), p. 115 en verder. 